\title{
Pedagogical Knowledge: A Reflection on the Pedagogical Praxis of Teachers during the Initial Phase of Their Profession
}

\author{
Alejandro Almonacid-Fierro ${ }^{1}$, Eugenio Merellano-Navarro, ${ }^{2, *}$, Sergio Sepúlveda-Vallejos ${ }^{3}$, \\ Marta Rios-Chandia ${ }^{2}$
}

${ }^{1}$ Faculty of Education, Universidad Católica del Maule, Talca, Chile

${ }^{2}$ Faculty of Education, Universidad Autónoma de Chile, Talca, Chile

${ }^{3}$ Doctorate in Education, Universidad Católica del Maule, Talca, Chile

Received September 28, 2020; Revised November 30, 2020; Accepted December 6, 2020

\begin{abstract}
Cite This Paper in the following Citation Styles
(a): [1] Alejandro Almonacid-Fierro, Eugenio Merellano-Navarro, Sergio Sepúlveda-Vallejos, Marta Rios-Chandia , "Pedagogical Knowledge: A Reflection on the Pedagogical Praxis of Teachers during the Initial Phase of Their Profession," Universal Journal of Educational Research, Vol. 8, No. 12B, pp. 8075-8084, 2020. DOI: 10.13189/ujer.2020.082609.
\end{abstract}

(b): Alejandro Almonacid-Fierro, Eugenio Merellano-Navarro, Sergio Sepúlveda-Vallejos, Marta Rios-Chandia (2020). Pedagogical Knowledge: A Reflection on the Pedagogical Praxis of Teachers during the Initial Phase of Their Profession. Universal Journal of Educational Research, 8(12B), 8075-8084. DOI: 10.13189/ujer.2020.082609.

Copyright $\mathrm{C} 2020$ by authors, all rights reserved. Authors agree that this article remains permanently open access under the terms of the Creative Commons Attribution License 4.0 International License

\begin{abstract}
The present article aims to understand and interpret the experiences that new teachers recall and learn from their initial teacher training. This will be conducted by understanding that knowledge is built daily through the exercise of teaching. In such a way that the experience and wisdom of pedagogical knowledge are consolidated through action and, given this context, praxis is not just an object of reflection, but an instance of learning for the exercise of teaching. Regarding methodology, this study stands from the interpretive paradigm and qualitative approach. To collect evidence, eight focus groups and twelve in-depth interviews were conducted with teachers who graduated from a Chilean university located in the center-south of the country. The sample was composed of a total of 53 teachers. As for data analysis, certain notions raised by grounded theory were utilized. The results of the study reveal the necessity - manifested by teachers-regarding initial training that allows for the construction of new knowledge and spaces to increase critical-reflective thinking. On the other hand, given their current pedagogical exercise within the classroom, teachers consider that initial teacher training must improve its theoretical-practical relationship, modify the curriculum and evaluation processes that are developed at university, consistently establish the university-school
\end{abstract}

link.

Keywords Novice Teachers, Reflective Praxis, Pedagogical Knowledge, Experiential Knowledge

\section{Introduction}

The knowledge carried by a teacher at the beginning of his/her teaching career can be understood as the set of personal, social, formative, and cultural experiences he/she has lived through. Likewise, it can be considered as the result of the appropriation of certain epistemological conceptions that have emerged throughout their different trajectories [19]. In this respect, knowledge can be understood as pedagogical knowledge or knowledge that is contextualized in a specific system (e.g., school practices) that reflects the conceptions, perceptions, experiences, beliefs, attitudes, expectations, and dilemmas that a teacher exhibits when beginning his/her teaching career. This knowledge or multiplicity of knowledge has rules and practical principles that are expressed through teaching lines of action [3], [42].

The Chilean educational system has undergone various 
transformations as a result of social, cultural, political, and economic changes in recent decades. Said changes have been characterized by the implementation of neoliberal market thinking, which sees education as a consumer good [6] and not as a social right in itself. In this context and under a system which only values results and rankings, teachers and those who are starting in the teaching profession have had to adapt and/or assume these demands and the problems that are typical of the socio-political reality and school context in which they are - and will be immersed. That is, those who are starting in the teaching profession must work within the existing model and from there, try to generate contributions and change from pedagogical practice to a social transformation. Before this scenario, the new teacher ${ }^{1}$ configures and reconfigures any preconceptions, beliefs, and visions he/she may have regarding the pedagogical knowledge and teaching exercise. An important aspect to consider and integrate into the formative processes of future teachers is the attributed characteristics of the role(s) that a teacher is expected to fulfil [14], [31].

Various researches and publications concerning the construction process of knowledge and pedagogical knowledge possessed by teachers point out that this is the result of the exercise and profession of teaching [8], [18], [40]. That is to say, experience, knowledge, and teaching praxis are consolidated through the teaching exercise. In this context, the teaching exercise must not only be seen as a reflection instance, but also as the moment when teachers recall their knowledge, experiences, and beliefs [29].

Authors such as König and Kramer [24], Marcelo and Vaillant [27], Shulman [35],[36], among others, express that teaching experience is a significant and constitutive aspect of professional knowledge. They also highlight the particular status that teachers attribute to this kind of knowledge, pointing out that it shapes and validates the teacher and his/her job. Professional experiences build and determine the teaching action, i.e., the sum of experiences build and define the pedagogical work of teachers [10]. In other words, pedagogical mastery is gradually acquired through the teaching exercise. However, the instances and tools used to build professional knowledge must be taught during the initial training [22]. A teacher provides a valuable and wide field of knowledge and learning opportunities to his/her students through his/her experience and pedagogical action; i.e., teachers that possess and share a diversity of experiences - both personal and professional-tend to perform a more conscious, consistent, and well-founded teaching exercise since they teach in accordance with what they have lived and experienced throughout their trajectories [21]. The teacher-as a social and cultural agent-must help students to overcome the obstacles that appear when

\footnotetext{
${ }^{1}$ Teacher with less than 5 years of work experience.
}

building their knowledge. Thus, teachers become problem situation managers within the classroom, using their experience and confronting it with their knowledge on a daily basis [24].

Regarding the relationship between theory and praxis, Korthagen [25] states that theory and praxis-by themselves and isolated from each other-do not lead to any pedagogical transformation, but when these complements and constitute each other are as inseparable elements, they are capable of promoting a significant change in the teaching exercise. In this respect, Freire [9] states that it is necessary to develop a critical consciousness concerning the relationship that must exist between theory and praxis, so that the correspondence and complementarity relationship promotes teaching as a process that enables transformations. Critical reflection on the praxis and theory is fundamental since, without it, neither theory nor praxis makes sense.

As for teacher training, it is not only present during initial training, but also during the set of professional internships since, to execute the praxis, a connection between the triad teacher, apprentice, and knowledge must exist. The Initial Teacher Training (ITT) must be the moment when critical reflection on the praxis is encouraged; this is a fundamental aspect since analyzing the current praxis allows for improving the future praxis [32], [33]. In this regard, the experiences lived through the pedagogical praxis influence the constitution of pedagogical knowledge that is originated in and from Initial Teacher Training; especially when teachers in training get into schools through internships. As stated by Stones [37], teaching internships represent the most valued element for both teachers in training and teachers working in the school system since, through them, it is possible to establish constant improvement processes regarding the teaching praxis. Likewise, novice teachers recognize and value the pedagogical internships they did during the ITT since, through them, it is possible to become acquainted with diverse contexts and educational realities, which allows for the acquisition of experiential knowledge and the constitution of teaching identity [4].

In this sense, it is necessary to recall the teacher's experiential knowledge; to this end, it is relevant that, during Initial Teacher Training, a close relationship between theory and praxis is established, aiming to establish dialogues and significant and constructive relationships between university and school, i.e., between theoretical bases and praxis [10].

Along the same line, when talking about the professional development of teachers, ITT accomplishes a fundamental role since it is in this period when the bases of this important process are established. On the other hand, the professional insertion experiences during the initial training processes are extremely relevant for future teachers as they promote the professional development of 
the latter. This development occurs-once they graduate - through continuous training, which contributes to maintaining a critical and reflective praxis [20].

In this context, the objective of the study is to understand and interpret the experiences that new teachers recall and put into practice from the ITT and the pedagogical practices experienced in this training period, to contribute to the strengthening of the teacher training processes and the link between university-school; school-university.

\section{Materials and Methods}

The present research stands from the interpretive paradigm and qualitative approach since its objectives aim to the interpretation of meanings through analysis and comprehension of the subjectivities of knowledge and experiences that novice teachers state [11], [30]. As for methodological design, the theoretical sampling proposed by Glaser and Strauss [15] was utilized, whose basic principle is to select cases or groups of cases following specific criteria concerning its content instead of using abstract methodological criteria [11]. The criteria used for sample characterization and selection of cases were: years of professional experience (the initial stage of the professional career - between one and five years); even distribution of the sample regarding gender; graduation year; career; and to be working as a teacher at the time of participating in the study.

To contact the participants, pertinent authorizations were requested to access the database of the pedagogy graduates from the eight careers belonging to the Faculty of Education of the participant university (see table $\mathrm{N}^{\circ} 1$ ), which is located in the center-south of Chile. The participants were contacted and invited to participate in the research through emails; it is worth noting that the meetings with novice teachers were conducted in the facilities of the university from where they graduated.

The background collection techniques used were focus groups and in-depth interviews; these were chosen since their characteristics allow for more participative, flexible, and close dialogues with the participants. Along this line, Gatti [12] and Given [16] point out that these techniques favor oral expression and dialogue between collaborators and between researcher and participants since they allow for sharing and reflecting on their life experiences. The script used in the focus groups and in-depth interviews was validated by five expert academics who, through a comprehensive review, contributed to the questions being specific and focused on the objectives set.

In the first stage, six focus groups were conducted; these were made up of a minimum of six and a maximum of eight participants. It is worth noting that six out of the eight planned focus groups were successfully carried out (one for each career). Two focus groups did not reach the minimum number of participants. Before this situation, it was decided to contact four novice teachers from the careers that did not reach the minimum of participants, and they were individually called to conduct an in-depth interview (see table $\mathrm{N}^{\circ} 1$ ). The second stage consisted of developing the in-depth interviews; to this end, eight key informants were called, who were selected from each focus group. The selection criteria were participation, disposition, and richness of opinions.

To proceed with the analysis of the collected background, the focus groups and in-depth interviews were transcribed. Data treatment was executed through the Nvivo 10 software. Likewise, the content analysis method was utilized to extract codes and categories inductively. These were reduced through the constant comparison method, which is circumscribed by the grounded theory [15], [38]. It is worth noting that the dimensions were obtained through revision of the theoretical framework [13]; categories and codes are grouped under these dimensions, which were obtained through the systematic and repeated reading of the participants' statements since, in this way, it was possible to approach the subjective experiences and meanings that novice teachers attach to their pedagogical praxis and Initial Teacher Training. The categories are presented in matrix form. As for the categorization process, main categories were established; more on this in the results section.

Table 1. Distribution and Instruments of data collection

\begin{tabular}{|c|c|c|}
\hline Careers & $\begin{array}{c}\text { Focus Groups } \\
\text { (number of } \\
\text { participants) }\end{array}$ & $\begin{array}{c}\text { In-depth } \\
\text { interviews }\end{array}$ \\
\hline $\begin{array}{c}\text { Visual Arts } \\
\text { Pedagogy }\end{array}$ & $1(6)$ & 1 \\
\hline $\begin{array}{c}\text { Primary Education } \\
\text { Pedagogy }\end{array}$ & - & 1 \\
\hline $\begin{array}{c}\text { Mathematics } \\
\text { Pedagogy }\end{array}$ & $1(7)$ & 2 \\
\hline $\begin{array}{c}\text { Physical Education } \\
\text { Pedagogy }\end{array}$ & $1(6)$ & 1 \\
\hline $\begin{array}{c}\text { History, Geography, } \\
\text { and Social Sciences } \\
\text { Pedagogy }\end{array}$ & $1(8)$ & 1 \\
\hline English Pedagogy & - & 1 \\
\hline $\begin{array}{c}\text { Spanish Language } \\
\text { and Communication } \\
\text { Pedagogy }\end{array}$ & $1(6)$ & 12 \\
\hline $\begin{array}{c}\text { Preschool Education } \\
\text { Pedagogy }\end{array}$ & $6(41)$ & \\
\hline Total & & \\
\hline
\end{tabular}

\section{Findings and Interpretation}

Any dimensions, categories, descriptors, and codes that emerged from the analysis and interpretation of the collected background are shown below (table $\mathrm{N}^{\circ} 2$ ). These were obtained from the six focus groups and twelve in-depth interviews conducted with novice teachers. 
Table 2. Data Systematization Matrix

\begin{tabular}{|c|c|c|c|}
\hline Megacategories & Categories & Descriptor & Code \\
\hline \multirow{6}{*}{$\begin{array}{l}\text { Reflection on } \\
\text { pedagogical } \\
\text { practices }\end{array}$} & \multirow{2}{*}{$\begin{array}{l}\text { Related to } \\
\text { the teacher }\end{array}$} & \multirow{2}{*}{$\begin{array}{l}\text { The category } \\
\text { that alludes } \\
\text { to the role of } \\
\text { the teacher }\end{array}$} & $\begin{array}{l}\text { Pedagogical } \\
\text { Relationship }\end{array}$ \\
\hline & & & $\begin{array}{c}\text { University } \\
\text { Teaching Staff }\end{array}$ \\
\hline & \multirow{4}{*}{$\begin{array}{l}\text { Related to } \\
\text { the process }\end{array}$} & \multirow{4}{*}{$\begin{array}{l}\text { Category } \\
\text { that presents } \\
\text { proposals } \\
\text { and/or } \\
\text { suggestions } \\
\text { regarding the } \\
\text { teacher } \\
\text { training } \\
\text { process }\end{array}$} & $\begin{array}{l}\text { Focused on the } \\
\text { Curriculum }\end{array}$ \\
\hline & & & $\begin{array}{l}\text { Related to } \\
\text { Evaluation }\end{array}$ \\
\hline & & & Related to ITT \\
\hline & & & $\begin{array}{l}\text { Related to } \\
\text { Practical } \\
\text { Training }\end{array}$ \\
\hline
\end{tabular}

For clarity, the description and interpretation of categories and codes obtained through the analysis of focus groups and in-depth interviews are presented. Likewise, the units of analysis (that were extracted from the statements) are presented in order to account for the codes and categories obtained. To differentiate the unit of analysis extracted from the focus groups (FG) from the ones extracted from the in-depth interviews (II), the nomenclature shown in parentheses is utilized. Likewise, the graduation career of the novice teacher is presented.

\subsection{Category: Pedagogical Relationships - Code: Pedagogical Relationship}

The "Pedagogical relationship" code acquires great importance since establishing a close relationship between teacher-tutor and teacher in training is fundamental for novice teachers. Furthermore, this relationship must offer instances of guidance during internships, where interaction between apprentice and teacher trainer exists; i.e., that his/her visit to the school isn't merely for inspection, but for providing help under a close relationship. Likewise, novice teachers declare that it is necessary to establish a relationship and communication between teacher trainer (university tutor) and supervising teacher (school tutor), i.e., that a true university-school and school-university relationship exists since, in this way, the professional practical experience can become an instance of gradual learning instead of an experience that generates anxiety and frustration. As for the relationships established by novice teachers at the beginning of their careers, they express that the pedagogical dialogue with their peers represents a source of learning; teaching experience and pedagogical knowledge acquire a relevant meaning. Moreover, a collaborative relationship based on dialogue, exchange of experiences, and teamwork allows them to build themselves as teachers.

I believe that the relationship between teacher trainers and intern students should be deeper. In my opinion, it should be closer, and not only focused on inspection. Perhaps there should be more field visits to facilitate the interaction between intern students and tutors. I think that would be interesting
(FG/Arts).

(...) in my opinion, communication channels are often not appropriate. There should be better communication between the tutor teacher from the university and the supervising teacher from the school because, depending on the school, some schools allow you to intervene progressively, while there are others where you arrive and they immediately make you responsible for a class (FG/Arts).

Teachers use different techniques. Some techniques work for some teachers, while others don't. For example, at school, we are always talking during recess, so I tell my colleague, you know what, this is how I worked with your class and it worked, that's how you build yourself as a teacher, through dialogue, through communication between peers, through collaborative work, through teamwork with teachers from other disciplines (FG/History and Geography).

Humans are social beings that co-build themselves through the relationships and interactions they establish with others. In this sense, forming teams, dialoguing, sharing experiences, and rethinking the teaching praxis become distinctive elements of the teaching staff that allow them to establish critical reflections on their praxis. To this end, it is necessary that collaboration spaces within schools and among peers exist. In this respect, teacher training and supervising teachers (who supervise novice teachers) must possess a solid human formation, as school is a scenario of social and affective relationships where the interactions between practice teachers and supervising teachers are fundamental [20].

On the other hand, the teaching praxis - especially at its beginning - must be seen as a collective construction of learning that is constructed under a close relationship. Practice teachers demand a closer relationship with the tutor teachers from the university and the supervising teacher to share their initial teaching experiences with other colleagues, thus learning from them, as well as from the shared experiences between novice and experimented teachers [2]. In this regard, the school everyone aspires to must be regulated under the logic of a space that allows for the establishment of collaborative relationships in a solidary society and democratic school where reflective and critical citizens are formed.

When observing teachers within the school space, the different subjectivities built through the pedagogical relationship between teachers and students within the community must be comprehended and valued to open collaborative listening and meeting spaces, as the subjects of the present study state. However, novice teachers manifest the necessity of having strengthened the relationship they had with their tutor teachers during their internship processes, recognizing the relevance and importance of maintaining an effective relationship. They state that tutor teachers should be closer and establish 
better communication channels. The university must implement training processes for tutor teachers and have communication mechanisms that allow for a better pedagogical relationship between practice teachers and tutors. This relationship must be founded on guidance and direct dialogue throughout the process in which the practice teacher is inserted into the school reality.

\subsection{Category: Pedagogical relationships - Code: University Teaching Staff}

The "University Teaching Staff" code acquires great importance due to the need-manifested by teachers in training — of improving their training process, emphasizing the need of having good teachers. They point out that a teacher trainer must have expertise and knowledge concerning the subject they teach, besides being innovative, creative, reflective, and motivating. These characteristics would allow teachers in training to have a better role model when in the school context.

(...) to impart pedagogy at university, the best teachers must be teaching future teachers. This would guarantee a better education in general; because achieving excellence in training is hard; because we have been talking about this for a thousand years and we still have teachers stuck in the past (II-2/Primary Education).

We are asked to be innovative in the classroom, but at university, we had teachers that only used ppt presentations or only did lecture classes. We didn't have a role model or an example to follow. We could not say I am going to teach as this teacher did, or I am going to innovate as this great teacher did when I was at university (II/History).

My suggestion is that the classes should be more motivating and innovative, and with more interaction between peers. Because when I was in college, I had traditional classes, directive classes. I believe that college teachers should apply the theory they teach us. They should do more active and participatory classes because that's something I had to learn by myself at school (II/English).

The researched subjects point out that the task of the university is to present teaching devices; that classes should not be exclusively or mainly driven by the logic that guides knowledge development from a traditional perspective. In other words, these devices should be relevant to teachers and useful for their praxis. They must consider their needs and be coherent with their baggage, knowledge, and modes of symbolization and action [3]. However, it is necessary to take these initiatives further and make the faculties of Education or Educational Sciences a part of these spaces. This involves, above all, that teachers must participate in diverse ways in order to develop future teaching methods. The above is stated by understanding that, at university, there usually exists an illusion that innovating teaching practices is not necessary, or that these practices are not legitimate research objects. This mistake causes that the fundamentals of the pedagogical praxis of the college teacher are not questioned, referring, in particular, to the implicit postulates of the nature of knowledge related to teaching [23]. This illusion creates a large gap between taught and utilized theories. Consequently, academics develop teaching and learning theories that are only useful to others, to students and teachers within the school system, but that are unable to permeate the very teacher training faculties [28].

Novice teachers point out that a college teacher must possess characteristics that benefit and enrich the training process. Some characteristics they mention are innovation, content knowledge, and being a motivating agent towards learning. These attributes are similar to those present in studies that characterize a good college teacher, which demonstrates the relevance and importance of the teacher's role concerning the learning process of the teacher in training [41].

Pedagogical mastery is an aspect that is gradually acquired through the teaching exercise and reflection on the praxis. Nonetheless, the tools needed to approach the work carried out in the classroom and at school must be taught during initial training. In that regard, Tardif [40] points out that the objective of initial and permanent training should be to develop the skills that are needed for the teaching praxis at the different levels and modalities of the educational system.

It's worth noting that the educational theories learned during the initial training process do not have as much influence over novice teachers as the education styles that are observed and experienced through the university teaching staff praxis [34]. Maybe this is what teachers in training demand from the praxis of teacher trainers.

\subsection{Category: Pedagogical relationships - Code: Focused on the Curriculum}

The "Focused on the Training Curriculum" code aims to gather statements and reflections that novice teachers express concerning the training program they received at college. In accordance with the key informants' statements, the curriculum or training program is a fundamental piece for their training as teachers, since it is the moment when knowledge and attitudes that are useful for their teaching praxis are developed. Novice teachers point out the need for strengthening the curriculum, integrating training regarding the topic of group control and conflict resolution. These two aspects are the most required within the school context regardless of the economic and social reality of the establishment, as novice teachers manifest through the following statements:

We all have our own deficits; as for how I handle discipline, how I handle a kid that is having an attack, 
how I handle rebellious children, how I control a class. Because having control over class is very important, and I believe that fifty percent of what we do is measured at school. And you can see that some teachers can't control their classes, they do not have group control skills. Those topics weren't present when I was at college (II/Spanish).

Learning how to plan was also taught in just one semester. So, if you have to learn how to plan, a semester is not enough. I believe that one fundamental thing that is asked from teachers is that he or she knows how to plan. And I had to learn all those things on my own when I started working at a school. I didn't learn them when I was a college student (II/English).

I, I mean, I would like to add that area, because I remember that, when we were here, there were times when we were kind of lost. Because some people are not good at talking, I think that is my case, and others do not have that problem, maybe they have problems dealing with other people. So, I believe that there should be workshops or courses within the college curriculum where you are taught to talk in public, to have argument skills, to have oral skills (FG/History).

In this context, teachers in training should have the tools needed to manage conflicts and, consequently, to favor the learning process of their students. Another aspect mentioned by novice teachers refers to increasing the planning experiences, as they point out that the current curriculum only offers one semester of training on this topic, thus hindering their integration into the school reality. As a result of this, the first years of professional praxis are decisive for acquiring the feeling of competence and establishing work routines for their praxis. Even today, most teachers learn how to work in the classroom through trial and error [17]. This learning, often difficult and associated with what we call professional survival (that is to say when the teacher must prove his/her skills), leads to the building of experiential knowledge, which is then turned into professional certainties, professional devices, routines, class management models, and knowledge transmission models. These tools are associated with the curricular aspects of the teacher's job, i.e., with the subject they teach. Nevertheless, their praxis is hindered when, for example, they present deficits regarding unit planning, which is associated with the national curriculum, or when they do not have the skills to control their classes. ITT is not capable of addressing these topics in all their complexity [26], [27].

\subsection{Category: Related to the Process - Code: Related to Evaluation}

The "Related to Evaluation" code is vital since knowing the evaluation strategies, methodologies, and types used by the teaching staff favors the teaching process and, subsequently, as for the professional praxis, it guarantees a good performance in the classroom. In accordance with the participants' statements, the types of classes performed within the school context must be varied, presenting a content preparation and planning that generates interests among the students, and placing special emphasis on the evaluation procedures and tools used:

From my perspective, I think teachers should be evaluated, as well as their classes. Because principals don't check teacher performance within the classroom, they only check if the subjects are being taught, the contents that must be taught, but they don't observe how teachers do that, and what is more important, they don't see the evaluation tools teachers use (FG/Physical Education).

At college, we are asked to plan varied classes, using different pedagogical strategies. Therefore, evaluations should be innovative too, so we have to use our experience, and replicate the evaluation methods that good teachers used when we were at school or college (FG/Preschool Education).

As educators, we must constantly modify our evaluation strategies, because our students change too. I can't use a test or an instrument in a class this year and continue using the same method in the same grade the following year, because the children will be different. And when the world changes, so do the children's interests, so I must be capable of identifying those changes and evaluate children coherently, trying to develop new evaluation strategies (FG/ Mathematics).

At work, teachers take advantage of their own cultural capital, which comes from their life stories and former school cultures; they also benefit from the disciplinary knowledge acquired in college, as well as the didactic and pedagogical knowledge derived from their professional training; they also rely on curricular knowledge present in programs, guides, and textbooks; lastly, they take advantage of their own knowledge associated with work experience, of the experience of certain teachers, and of the very traditions of the teaching profession. With this capital, teachers elaborate and utilize evaluation strategies that allow them to value the progress of their students' learning [7]. Likewise, teachers state that the methodological and evaluation strategies for working with children must be more innovative and must offer more personalized attention to satisfy their needs.

\subsection{Category: Related to the Process - Code: Related to ITT}

The code "Related to ITT" includes a wide variety of reflections on the training process that teachers went through at college. The teacher in training needs to know how to teach and establish relationships and 
communication channels with his/her students. The aim of the above is that, when teachers start their professional careers, they are able to integrate into the school educational projects collectively and collaboratively, in accordance with what is stated by the researched teachers:

Concerning the university, I suggest that more emphasis is placed on methodologies for working with different kinds of children because you can see different realities within a classroom because each child learns at their own pace. Therefore, the university should teach us different strategies during our training process, since initial training is fundamental for our current professional performance (FG/Arts).

As for me, I also consider that there is a lack of methodologies. There should be more methodology courses; besides, these courses should be more didactic, taking into account the nature of the discipline. For example, we are primary education teachers, so we should know how to work with different materials for each content. So, besides learning how to teach a class with few materials, we should do things that would actually work when teaching at a school, for example, learning how to work at a vulnerable school, such as the one where I currently work (II/Physical Education).

There should be feedback spaces where students that graduated from the Faculty of Education participate. Or, perhaps, hold a feedback seminar alongside the former students that are already working to share and present our experiences to the new generations. That would be my suggestion for the faculty; in this way, they could know what is happening in the different work realities and then incorporate this information into the university training courses (II/Primary Education).

The pedagogical knowledge that teachers acquire through their daily life and daily work at school is the basis of their teaching praxis, i.e., the knowledge that allow teachers to interact with their students in the classroom, within the context of the educational institution where they work. In this sense, the teaching praxis is both an expression of this built pedagogical knowledge and a source for its development [1]. On the other hand, disciplinary knowledge is offered and selected by the university institution through the diverse disciplines it offers. That is to say, the knowledge available in society that is transmitted through programs and departments, which originates from cultural tradition and social groups that produce disciplinary knowledge and specifically, pedagogical content knowledge [23]. The above allows for the building of knowledge, which can generate significant changes to the teaching praxis within the classroom, such as the ones pointed out by the researched teachers concerning the articulation between theory and praxis, planning and selection of innovative methodologies, and learning how to teach in vulnerable contexts and with scarce materials.

In this context, specific knowledge regarding praxis changes. Pedagogical knowledge must be reviewed and modified in accordance with the social dynamics that occur within the classroom, as knowledge and pedagogical knowledge need to include a process that supports and allows for the creation and production of knowledge in a constantly changing world [24]. Consequently, the initial training processes at college must be modified and updated following the new demands of the school system; in this regard, key informants demand more didactic alternatives, training in diverse contexts, and more contact between university and school.

\subsection{Category: Related to the Process - Code: "Related to Practical Training"}

The "Related to Practical Training" code includes a set of reflections made by novice teachers regarding the practical training they received at college. Based on the key informants' statements, it can be observed that the teachers' professional knowledge is not only personalized but also situated, i.e., it is built and utilized in accordance with a specific work context, and it is within this specific context where that knowledge will work:

(...) I consider that, at college, little importance is attached to the first approaches to the school context since there exists no supervision. I believe that they are fundamental instances for our learning process, even if they are not supervised. I sometimes felt a degree of insecurity in regards to knowing if what we were doing was correct..., so, I do believe that the instances that exist are positive, but they lack a real supervision process led by the tutor teachers from the university. The only supervision instance I had with a tutor teacher was during my internship; the other instances were only sporadic reunions or an hour a week that didn't provide me with the contributions I needed to keep teaching my classes at school. Therefore, as for universities, I think that it doesn't make sense to keep internships in the curriculum if they are not going to supervise them (FG/Physical Education).

I think that the main problem is related to duration. For example, I remember that, during my second year at college, I was sent to a school, but I only had to attend two or three classes. So you don't truly become aware of the real problems that exist at the school, because you attend as an external agent, with no chances of intervention (FG/History).

Yes, I do consider that it is valuable to go to schools to observe as a first approach to the school context. However, it should be a longer process that doesn't only consist of attending to a couple classes, because 
you don't become aware, you can't perceive the teaching challenges (II/Preschool Education).

In accordance with the key informants' statements, the meanings assigned by teachers and students to the teaching situations are elaborated and shared within these very situations. In other words, they anchor and locate within the very situations they help define. These anchoring phenomena lead many researchers to become interested in situated cognition and contextualized learning, according to which knowledge is built by agents in accordance with the work context, i.e., the pedagogical praxis that configures the teachers' practical knowledge [19].

On the other hand, teacher training courses are developed globally following an applicative knowledge model, i.e., students spend a defined number of years attending classes at college; these classes are based on discipline and are composed of purposeful knowledge. Subsequently, or during these classes, students have to start using this knowledge. Lastly, when training ends, teachers start working by themselves, learning to do their jobs through practice and finding, most of the time, that this purposeful knowledge doesn't work for the daily praxis. Consequently, it is fundamental that teacher training considers the close link between praxis and theory [33]. This applicative model is not only ideological and epistemological but a model that is institutionalized through the university's internship and career system. In this context, the investigated subjects suggest that the process should be improved in regard to the need for a stronger link between university and teacher in training, aiming to generate systematic feedback.

\section{Conclusions and Suggestions}

Reflective practice and pedagogical knowledge acquire importance as they are understood as knowledge sources and, consequently, as constant processes of learning and knowledge building [9]. Along this line, it can be stated that reflection is a characteristic element of the human being that is produced through its social relationships. Therefore, teacher training requires a solid human formation, and school must be seen as a social relationships scenario where teachers have a fundamental role, as teaching is not about transferring knowledge, but rather about offering conditions through which students can produce their own knowledge, thus confirming the idea that critical learning is possible [5].

In this context, knowledge is built daily through the teaching praxis in such a way that experience, and pedagogical knowledge consolidate the action and, thereby, practice is not only an object of reflection but of resignification. In this way, the reflective teaching praxis becomes prominent and is understood as a source of knowledge and a place of knowledge building, as researched subjects express through the different statements that have been systematized and interpreted in previous sections. As it has been mentioned above, the presented categories account for both similarities and differences between the key informants' statements; nevertheless, the experiential knowledge topic can be identified in all of them. This topic is present in works developed by authors such as Korthagen [25], Shulman [35],[36], Tardif [39], Vaillant [41], among others, who identify experience as a category of professional knowledge, highlighting the particular status that teachers attach to it.

Consequently, when knowledge is built and conquered by teachers, it constitutes their praxis, showing their successes and failures. In this sense, professional learning is reflected through the teaching praxis, by presenting a solid knowledge base and by providing students with a valuable and wide learning field. Along the same line, we can state that research, training, and practice are complementary and synergistic elements that are fundamental for developing quality training for future teachers. Therefore, the suggestions made by novice teachers are fundamental to reorient the teacher training processes within the framework of the development of a pedagogical knowledge that is signified and re-signified from the teaching praxis.

The teachers' statements and the urgency of the categories reported in the study show that the novice teachers that were selected as key informants develop a reflective praxis. This can be observed when they make improvement proposals regarding ITT, recognizing the complexities of teaching and the aspects associated with the role of the teacher in terms of the human and professional relationships that are developed within the school; additionally, it can be observed by how they understand the role of university teachers, suggesting greater innovation in regard to the ITT didactic-pedagogical processes. Furthermore, the researched subjects explicitly state the aspects that, in their opinion, could improve the initial teacher training processes. This is relevant when considering that the knowledge they received at college is currently being questioned and tested within the classroom. Based on the above, they state the need for improvements regarding the teacher training curriculum, a more coherent evaluation process, and practical training that allows for recursively linking theory and praxis.

We predict that this research gives us new ways of observing the phenomenon of study, either through the view held by mentor teachers (expert teachers) of the initial training and pedagogical practice that new teachers develop; also, from the expert teachers' own experiences of starting out in the teaching profession. These research predictions will eventually allow us to broaden study of the problem, since collecting the recommendations and experiences of expert teachers on pedagogical practice and the various transformations of the Chilean school system 
can be an important input in the strengthening of the FID and in the accompaniment processes that are provided to those who are starting in the teaching profession. This is a stage of the professional trajectory that is faced with great challenges.

The summation of these two perspectives (of new teachers and expert teachers) will allow further research to be carried out that gives weight to a proposal for improvement of the IDF and/or the development of an intervention and support plan for new teachers that is, contextualized to individual needs. The latter can prove useful to school management teams in the development of an effective and meaningful accompaniment to trainee teachers, which will not only strengthen the integration and well-being of new teachers but will also intervene in their work pedagogically.

\section{Acknowledgments}

We are very grateful to experts for their appropriate and constructive suggestions to improve this template.

\section{REFERENCES}

[1] S. Abell, "Twenty years later: Does pedagogical content knowledge remain a useful idea?", International Journal of Science Education, vol. 30. No. 10, pp. 1405-1416. DOI: 10.1080/09500690802187041, 2008 .

[2] R. Akbari and L. Tajik, "L2 teachers' pedagogical Knowledge base: A comparison between experienced and inexperienced practitioners", Australian Journal of teacher Education, vol. 34, no. 6, pp. 52-73. DOI: 10.14221/ajte.2009v34n6.4, 2009.

[3] K. Bain, "What the best college teachers do", Harvard University Press, 2004.

[4] D. Beijaard, P. Meijer and N. Verloop, "Reconsidering research on teachers professional identity", Teaching and Teacher Education, vol. 20, pp. 107-119. DOI:10.1016/j. tate.2003.07.001, 2004

[5] M. Baxter, "Evolution of a constructivist conceptualization of epistemological reflection", Educational Psychologist, vol. 39, no. 1, pp. 31-42. DOI:10.1207/s15326985ep3901_4, 2004.

[6] C. Bellei and C. Cabalin, "Chilean student movements: sustained struggle to transform a market-oriented educational system", Current issues in comparative education, vol. 15, no. 2, pp. 108-123, 2013.

[7] E. Cauet, S. Liepertz, A. Borowski and H. E. Fischer, "Does it matter what we measure? Domain-specific professional knowledge of physics teachers", Schweizerische Zeitschrift für Bildungswissenschaften, vol. 37, no. 3, pp. 462-479, 2015.

[8] K. K. H. Chan and B. H. Yung, "Developing pedagogical content knowledge for teaching a new topic: More than teaching experience and subject matter knowledge", Research in Science Education, vol. 48, no. 2, pp. 233-265. DOI:10.1007/s11165-016-9567-1, 2018.

[9] P. Freire, "Pedagogy of autonomy: knowledge necessary for educational practice". Sao Paulo: Peace and Earth, 1996.

[10] F. M. Forzani, "Understanding "core practices" and "practice-based" teacher education learning from the past", Journal of Teacher Education, vol. 65, no. 4, pp. 357-368. DOI:10.1177/0022487114533800, 2014.

[11] U. Flick, "An introduction to qualitative research", 4a ed., Los Angeles, CA: SAGE Publications, 2009.

[12] B. Gatti, "Grupo focal na pesquisa em ciências sociais e humanas”, Brasília: Líber Livro, 2005.

[13] G. Gibbs, "Analyzing qualitative data", Los Angeles, CA: SAGE Publications. DOI:10.4135/9781849208574, 2007.

[14] D. Gitomer and R. Zisk, "Knowing what teachers know". Review of Research in Education, vol. 39, no. 1, pp. 1-53. DOI:10.3102/0091732X14557001, 2015.

[15] G. Glaser and L. Strauss, "The discovery of grounded theory: strategies for qualitative research", New York, Adline de Gruyter, 1967.

[16] L. M. Given, "The Sage encyclopedia of qualitative research methods", Thousand Oaks, New York: Sage, 2008.

[17] E. Gatbonton, 'Looking beyond teachers' classroom behaviour: Novice and experienced ESL teachers' pedagogical knowledge", Language Teaching Research, vol. 12, no. 2, pp. 161-182. DOI:10.1177/1362168807086286, 2008 .

[18] J. Gess-Newsome, J. A. Taylor, J. Carlson, A. L. Gardner, C. D. Wilson and M. A. M. Stuhlsatz, "Teacher pedagogical content knowledge, practice, and student achievement", International Journal of Science Education, vol. 41, no. 7, pp. 16-36. DOI:10.1080/09500693.2016.1265158, 2017.

[19] K. Gholami and J. Husu, "How do teachers reason about their practice? Representing the epistemic nature of teachers' practical knowledge", Teaching and Teacher Education, vol. 26, no. 8, pp. 1520-1529, DOI:10. 1016/j.tate.2010.06.001, 2010 .

[20] D. Graham, A. Greg and W. Hastings, "Collaborative feedback and reflection for professional growth: preparing first- year pre-service teachers for participation in the community of practice", Asia Pacific Journal of Teacher Education, vol. 41, no. 2, pp. 159-172. DOI:10.1080/1359866X.2013.777025, 2013.

[21] J. Großschedl, U. Harms, T. Kleickmann and I. Glowinski, "Preservice biology teachers' professional knowledge: Structure and learning opportunities", Journal of Science Teacher Education, vol. 26, no. 3, pp. 291-318. DOI:10.1007/s10972-015-9423-6, 2015.

[22] S. Kaivanpanah, A. A. Rezaee and M. Neamatollahi, "The influence of strategic mediation on novice EFL teachers' pedagogical knowledge", Journal of Modern Research in English Language Studies, vol. 4, no. 2, pp. 107-89, 2017.

[23] V. Kind and K. K. Chan, "Resolving the amalgam: connecting pedagogical content knowledge, content 
knowledge and pedagogical knowledge", International Journal of Science Education, vol. 41, no. 7, pp. 964-978. DOI:10.1080/09500693.2019.1584931, 2019.

[24] J. König and C. Kramer, "Teacher professional knowledge and classroom management: On the relation of general pedagogical knowledge (GPK) and classroom management expertise (CME)", ZDM Mathematics Education, vol. 48, no. 1, pp. 139-151. DOI:10.1007/s11858-015-0705-4, 2016.

[25] F. Korthagen, "The relationship between theory and practice in teacher education", International encyclopedia of education, vol. 7, pp. 669-675, 2010.

[26] M. Kunter, U. Klusmann, J. Baumert, D. Richter, T. Voss and A. Hachfeld, "Professional competence of teachers: Effects on instructional quality and student development", Journal of Educational Psychology, vol. 105, no. 3, pp. 805820. DOI:10.1037/a0032583, 2013.

[27] C. Marcelo and D. Vaillant, "Ensinando a ensinar: as quatro etapas de uma aprendizagem", Curitiba: Ed. Universidade Tecnologica Federal de Paraná, 2012.

[28] M. Milner-Bolotin, "Evidence-based research in STEM teacher education: From theory to practice", In Frontiers in Education, Vol. 3, no. 92, pp. 1-9.

DOI:10.3389/feduc.2018.00092, 2018.

[29] E. Merellano-Navarro, A. Almonacid-Fierro and $M$. Muñoz-Oyarce, "Resignificando el saber pedagógico: una mirada desde la práctica docente", Educação e Pesquisa, vol. 45, pp. 1-18. DOI:10.1590/s1678-4634201945192146, 2019.

[30] A. Moreira and A. P. Costa, "Introduction: qualitative analysis: quantifying quality and qualifying quantity", The qualitative report, vol. 21 , no. 13, pp. 1-5. Retrieved from https://nsuworks.nova.edu/tqr/vol21/iss13/1, 2016.

[31] M. Özbas and D. Mukhatayeva, "Views of pre-Service teachers related to the development of pedagogical formation training and design competences", Universal Journal of Educational Research, vol. 6, no. 6, pp. 1207-1215, 2018.

[32] M. L. Pérez Cañado, "Innovations and challenges in CLIL teacher training", Theory Into Practice, vol. 57, no. 3, pp. 1-10. DOI:10.1080/00405841.2018.1492238, 2018.

[33] J. Rasmussen and A. Rash-Christensen, "How to improve the relationship between theory and practice in teacher education", Educational Research for Policy and Practice, vol. 14, no. 3, pp. 213-230.DOI:10.1007/s10671-015-91805,2015 .

[34] J. Samples and S. Copeland, "The universality of good teaching: a study of descriptores across Disciplines", International journal of teaching and learning in higher education, vol. 23, no. 2, pp. 176-188, 2013.

[35] L. Shulman, "Paradigms and research programs in the study of teaching: A contemporary perspective", In M. C. Wittrock (Ed.), Handbook of research in teaching pp. 3-36. New York, NY: Macmillan, 1986.

[36] L. Shulman, "Knowledge and teaching: foundations of the new reform", Harvard educational review, vol. 57, no. 1, pp. 1-23. DOI:10.17763/haer.57.1.j463w79r56455411, 1987.

[37] E. Stones, "Pedagogical studies in the theory and practice of teacher education", Oxford Review of Education, vol. 15, no. 1, pp. 3-15. DOI:10.1080/0305498890150101, 1989.

[38] A. Strauss and J. M. Corbin, "Basics of qualitative research: grounded theory procedures and techniques", Thousand Oaks, CA: SAGE Publications, 1990.

[39] M. Tardif, "Los saberes del docente y su desarrollo profesional”, Madrid: Narcea, 2004.

[40] M. Tardif, "A profissionalização do ensino passados trinta anos: dois passos para a frente, três para tras", Educação \& Sociedade, vol. 34, no. 123, pp. 551-571. DOI:10.1590/S0101-73302013000200013, 2013.

[41] D. Vaillant, "Formación inicial del profesorado en América Latina : dilemas centrales y perspectivas", Revista Española de Educación Comparada, no. 22, pp. 185-206. DOI:10.5944/reec.22.2013.9329, 2013

[42] N. Verloop, J. Van Driel and P. C. Meijer, "Teacher knowledge and the knowledge base of teaching", International Journal of Educational Research, vol. 35, no. 5, pp. 441-461. DOI:10.1016/S0883-0355(02)00003-4, 2001. 